\title{
Polymerase Chain Reaction Detection of Enterotoxins Genes in Coagulase-Negative Staphylococci Isolated from Brazilian Minas Cheese
}

\author{
Vera Lúcia Mores Rall, ${ }^{1}$ José Maurício Sforcin,, Maria Fernanda Ramos de Deus, \\ Daniel Casaes de Sousa, Carlos Henrique Camargo,' Natália Cristina Godinho, \\ Luciane Almeida Galindo, ${ }^{2}$ Taíssa Cook Siqueira Soares, and João Pessoa Araújo, Jr.
}

\begin{abstract}
For a long time, Staphylococcus aureus has been always thought to be the only pathogenic species among Staphylococcus, while coagulase-negative staphylococci (CNS) were classified as contaminant agents. However, molecular techniques have shown that these microorganisms also possess enterotoxin-encoding genes. The aim of this study was to analyze the frequency of genes for staphylococcal enterotoxins SEA, SEB, SEC, and SED in CNS strains isolated from Minas soft cheese and to assess the in vitro production of toxins. CNS were found in 65 (72.2\%) samples of cheese: 23 were Staphylococcus saprophyticus, 16 Staphylococcus warneri, 10 Staphylococcus epidermidis, 9 Staphylococcus xylosus, 3 Staphylococcus haemolyticus, 2 Staphylococcus schleiferi subsp. schleiferi, and 1 each Staphylococcus capitis subsp. urealyticus and Staphylococcus caprae. Seventeen (26.2\%) CNS strains had genes for enterotoxins, and sea was more frequently found (18.5\%), followed by sec in three and seb in two strains, whereas the sed gene was not found. S. saprophyticus showed enterotoxin genes in 6 of 23 isolates, but only sea was observed. On the other hand, five strains of S. warneri showed the sea, seb, or sec gene. In spite of the presence of these enterotoxin genes, these strains did not produce enterotoxins in vitro. It is essential to understand the real role of CNS in food, and based on the presence of enterotoxin genes, CNS should not be ignored in epidemiological investigations of foodborne outbreaks.
\end{abstract}

\section{Introduction}

E NTEROTOXIGENIC STAPHYLOCOCCUS AUREUS is one of the $\mathrm{C}_{\text {major }}$ pathogens causing food poisoning worldwide (Dinges et al., 2000). It has been considered the only pathogenic species among Staphylococcus, while coagulase-negative staphylococci (CNS) have been classified just as contaminant agents (Kloos and Bannerman, 1994). Recently, several authors have suggested that this group of microorganisms should be studied regarding the presence of enterotoxin genes (Rodriguez et al., 1996; Veras et al., 2008; Rall et al., 2010).

In Brazil, Minas cheese is the most popular cheese consumed all over the country. It is a soft and fresh white cheese with high $\mathrm{pH}, 55 \%$ moisture content, and low percentage of salt $(1.4 \%-1.6 \%)$. It is produced on both industrial and domestic scales by adding lactic cultures or by direct acidification of milk (Carvalho et al., 2007). In a minor-scale production, small producers use raw milk in nonhygienic conditions. Besides the nonpasteurized milk, Staphylococcus genus from the food handler may contaminate Minas cheese (Carmo et al., 2004). The present study aimed to analyze the frequency of the sea, seb, sec, and sed genes in CNS strains isolated from samples of Minas soft cheese and to evaluate their ability to produce enterotoxins in vitro.

\section{Materials and Methods}

\section{Microbiological analysis}

We analyzed 90 samples of Minas cheese from 16 different brands collected from supermarkets and dairy product stores in Botucatu, São Paulo State, Brazil. Twenty-five grams of each sample was homogenized in $225 \mathrm{~mL}$ of buffered sterilized water using a Stomacher Lab Blender 400 (Seward) for $30 \mathrm{~s}$, and several decimal dilutions were performed using the same diluent.

\section{CNS identification}

Serial dilutions were plated on Baird-Parker agar with $5 \%$ egg yolk tellurite emulsion and incubated at $35^{\circ} \mathrm{C}$ for $48 \mathrm{~h}$. 
Five characteristic colonies were tested for catalase and coagulase. After this screening test, antibiogram test for bacitracin $(0.04 \mathrm{U})$ and furazolidone $(100 \mu \mathrm{g})$ was applied to discriminate CNS from Kocuria (Bannerman and Peacock, 2007). Finally, the strains were submitted to API Staph (Biomérieux).

\section{Polymerase chain reaction test for genes encoding staphylococcal enterotoxins}

DNA was extracted using a commercial kit (Mini Spin Kit; GE Healthcare) following the supplier's instructions. The primers used to detect the SE genes and the polymerase chain reaction were performed according to Johnson et al. (1991).

Samples of sea, seb, and sec amplicons were sequenced and the partial sequences were confirmed as corresponding to GenBank accessions numbers M18970, M11118, and X05815, respectively.

\section{In vitro enterotoxin production}

Enterotoxin production was analyzed according to Donnelly et al. (1967). The supernatants were tested for SEA, SEB, SEC, and SED using the reversed passive latex agglutination assay method (RPLA) (Oxoid-SET-RPLA) according to the manufacturer's instructions. American Type Culture Collection (ATCC) strains were used as positive controls.

\section{Results}

CNS were found in 65 of 90 samples (72.2\%): 23 (35.4\%) were Staphylococcus saprophyticus, 16 (24.6\%) Staphylococcus warneri, 10 (15.4\%) Staphylococcus epidermidis, 9 (13.8\%) Staphylococcus xylosus, 3 (4.6\%) Staphylococcus haemolyticus, 2 (3.1\%) Staphylococcus schleiferi subsp. schleiferi, and each one of $(1.5 \%)$ Staphylococcus capitis subsp. urealyticus and Staphylococcus caprae. Simultaneous presence of two species in the same sample was also observed: one of them showing $S$. saprophyticus and S. warneri, and the other S. warneri and $S$. epidermidis.

Table 1 shows the results of molecular tests for the sea, seb, sec, and sed genes detection, and sea was the most frequent gene $(18.5 \%)$. S. warneri was the only species presenting strains with the sea, seb, and sec genes.

Table 1. Genotypic Profile of the SEA, SEB, SEC, and $S E D$ Genes in Coagulase-Negative Staphylococci Isolated from Minas Cheese

\begin{tabular}{lrrrrr}
\hline & \multicolumn{5}{c}{ Classic enterotoxins genes } \\
\cline { 3 - 7 } Species & $\mathrm{n}$ & sea & seb & sec & sed \\
\hline Staphylococcus saprophyticus & 23 & 6 & - & - & - \\
Staphylococcus warneri & 16 & 2 & 1 & 2 & - \\
Staphylococcus xylosus & 9 & 2 & - & 1 & - \\
Staphylococcus haemolyticus & 3 & 1 & 1 & - & - \\
Staphylococcus schleiferi & 2 & - & - & - & - \\
$\quad$ subsp. schleiferi & & & & & \\
Staphylococcus capitis & 1 & 1 & - & - & - \\
$\quad$ subsp. urealyticus & & & & & \\
Staphylococcus epidermidis & 10 & - & - & - & - \\
Staphylococcus caprae & 1 & - & - & - & - \\
Total & 65 & 12 & 2 & 3 & - \\
\hline
\end{tabular}

Despite the presence of the enterotoxin genes, these strains did not produce enterotoxins in vitro.

\section{Discussion}

S. aureus is one of the most prevalent pathogens in food, causing several outbreaks (Veras et al., 2008), but the potential of CNS to cause foodborne disease is not clearly elucidated.

The enterotoxin genes in CNS have been described using polymerase chain reaction techniques. Herein, 17 (26.2\%) CNS strains presented genes for classical enterotoxin production. A similar percentage was observed by Rall et al. (2010), with $19.4 \%$ of CNS isolated from food handlers. A lower prevalence was observed by Vernozy-Rozand et al. (1996), with $5.3 \%$ of the microorganisms isolated from goat milk and cheese presenting enterotoxin genes, and by Rosec et al. (1997), who found that all of 264 CNS strains were negative for these genes. On the other hand, sec and sed were present in $57.1 \%$ of CNS isolated by Rodriguez et al. (1996). Veras et al. (2008) found five out of eight $(62.5 \%)$ of CNS encoding such genes.

The sea gene was found more frequently (18.5\%), while sed was not observed. The SE genes seb and sec were found in similar percentages $(3.1 \%$ and $4.6 \%$, respectively). Rall et al. (2010) observed that sea also occurred more frequently among classical enterotoxin genes $(24.1 \%$ of CNS).

Despite the presence of classical enterotoxin genes in $26.2 \%$ of CNS strains, none of them produced enterotoxins in vitro as evaluated by RPLA method. This result is in agreement with Harvey and Gilmour (1988, 1990), who showed that none of 353 and 384 strains of CNS isolated from goats milk and milk powders produced enterotoxins, respectively. One may speculate that it might be due to the low amounts of SEs production, which is not detectable by the method. Enterotoxin was produced using sac culture methods, which are considered to be the most efficient techniques (Robbins et al., 1974), and according to the manufacturer's instructions, the sensitivity of the Kit has been reported to be $0.5 \mathrm{ng} / \mathrm{mL}$. Besides, all ATCC controls produced enterotoxins. Thus, probably these isolates were not expressing the enterotoxin genes. According to Robbins et al. (1974), CNS poorly produce enterotoxins even in optimal conditions. Besides, defects in toxin expression may occur due to point mutations that convert the toxin genes to silent genes (Okoji et al., 1993).

However, several authors have shown that enterotoxin production may be highly variable. Crass and Bergdoll (1986) observed that $10 \%$ of CNS isolated from food and animals were enterotoxin producers. A percentage of $5.3 \%$ was reported by Vernozy-Rozand et al. (1996), whereas Zell et al. (2008) reported that $45.7 \%$ of CNS isolated from food produced enterotoxins. Veras et al. (2008) observed that $62.5 \%$ of these microorganisms isolated from outbreaks were enterotoxin producers as well. Taken together, our data and those from literature point out that CNS should not be ignored in epidemiological studies of foodborne outbreaks, because the presence of genes for enterotoxins indicates the potential ability of those species to synthesize the proteins. Therefore, further investigations on the role of such genes are still required. 


\section{Acknowledgments}

The authors thank Fundação de Amparo ã Pesquisa do Estado de São Paulo (FAPESP) for fellowship, Fundação para o Desenvolvimento da UNESP (FUNDUNESP) for financial support, and Dr. Ramon Kaneno for critical review of the article.

\section{Disclosure Statement}

No competing financial interests exist.

\section{References}

Bannerman TL and Peacock SJ. Staphylococcus, Micrococcus and other catalase-positive cocci. In: Manual of Clinical Microbiology. Murray PR, Baron EJ, Jorgensen JH, Landry ML, and Pfaller MA (eds.). Washington DC: ASM Press, 2007, pp. 390411.

Carmo LS, Cummings C, Linardi VR, Dias RS, Souza JM, Sena MJ, Santos DA, Shupp JW, Pereira RKP, and Jett M. A case study of a massive staphylococcal food poisoning incident. Foodborne Pathog Dis 2004;1:241-246.

Carvalho JDG, Viotto WH, and Kuaye AY. The quality of Minas frescal cheese produced by different technological processes. Food Control 2007;18:262-267.

Crass BA and Bergdoll MS. Involvement of coagulase negative staphylococci in toxic shock syndrome. J Clin Microbiol 1986; 23:43-45.

Dinges MM, Orwin PM, and Schlievert PM. Exotoxins of Staphylococcus aureus. Clin Microbiol Rev 2000;13:16-34.

Donnelly CB, Leslie JE, Black LA, and Lewis KH. Serological identification of enterotoxigenic staphylococci from cheese. Appl Microbiol 1967;15:1382-1387.

Harvey $\mathrm{J}$ and Gilmour A. Isolation and characterization of staphylococci from goats milk produced in Northern Ireland. Lett Appl Microbiol 1988;7:79-82.

Harvey J and Gilmour A. Isolation and identification of staphylococci from milk powders produced in Northern Ireland. J Appl Microbiol 1990;68:433-438.

Johnson WM, Tyler SD, Ewan FE, Ashton FR, Pollard DR, and Rozee KR. Detection of genes for enterotoxins, exfoliative toxins, and toxic shock syndrome toxin 1 in Staphylococcus aureus by the polymerase chain reaction. J Clin Microbiol 1991;29:426-430.
Kloos WE and Bannerman TL. Update on clinical significance of coagulase-negative staphylococci. Clin Microbiol Rev 1994;7: $117-140$

Okoji CN, Inglis B, and Stewart PR. Potential problem in the use of oligonucleotide probes for staphylococcal enterotoxin genes. J Appl Bacteriol 1993;74:637-644.

Rall VLM, Sforcin JM, Augustini VCM, Watanabe MT, Fernandes A Jr., Rall R, Silva MG, and Araújo JP Jr. Detection of enterotoxin genes of Staphylococcus sp isolated from nasal cavities and hands of food handlers. Braz J Microbiol 2010;40:1067-1073.

Robbins R, Gould S, and Bergdoll MS. Detecting the enterotoxigenicity of Staphylococcus aureus strains. Appl Microbiol 1974;28:946-950.

Rodriguez M, Nunez F, Córdoba JJ, Bermudez E, and Asensio MA. Gram positive catalase-positive cocci from dry cured Iberian ham and their enterotoxigenic potential. Appl Environ Microbiol 1996;62:1897-1902.

Rosec JP, Gigaud O, Dalet C, and Richard N. Enterotoxin production by staphylococci from foods in France. Int J Food Microbiol 1997;35:213-221.

Veras JF, Carmo LS, Tong LC, Shupp JW, Cummings C, Santos DA, Cerqueira MMOP, Cantini A, Nicoli JR, and Jett M. A study of the enterotoxigenicity of coagulase negative and coagulase positive staphylococcal isolates from food poisoning outbreaks in Minas Gerais Brazil. J Infect Dis 2008;12:410-415.

Vernozy-Rozand C, Mazuy C, Prevost G, Lapeyre C, Bes M, Brun $Y$, and Fleurette J. Enterotoxin production by coagulase negative staphylococci isolated from goat's milk and cheese. Int J Food Microbiol 1996;30:271-280.

Zell C, Resch M, Rosenstein R, Albrecht T, Hertel C, and Götz F. Characterization of toxin production of coagulase-negative staphylococci isolated from food and starter cultures. Int J Food Microbiol 2008;127:246-251.

Address correspondence to: Vera Lúcia Mores Rall, Ph.D. Department of Microbiology and Immunology Institute of Biosciences São Paulo State University-UNESP

P.O. Box 510

Botucatu 18618-000

São Paulo

Brazil

E-mail: vlmores@ibb.unesp.br 
